\title{
Possible effects of erythropoietin on diabetic rats
}

\author{
Ahmed Mostafa Mahmoud ${ }^{1}$, Hassan Mohamed Elalaf ${ }^{1}$, Walaa \\ Mohamed Shaaban $^{1}$, Motamed E. Mahmoud ${ }^{2}$
}

${ }^{1}$ Department of Physiology, Faculty of Medicine, Sohag University, Sohag, Egypt.

2 Department of Animal Behavior and Husbandry, Faculty of Veterinary Medicine, Sohag, University, Sohag, Egypt.

\begin{abstract}
Background: Blood glucose is controlled by a pancreatic hormone, insulin, so any altered functions of the pancreas are associated with disturbances in blood glucose level. Erythropoietin (EPO) is glycoprotein produced mainly by the kidney as a result of reduced intracellular oxygen. This study was designed to investigate the effect of EPO on blood glucose level in normal and streptozocin-induced diabetic rats.

Materials and methods: Eighty mature rats were used in this study animals and randomly divided into 4 different isolated groups $(n=20)$; Group I was administered with normal saline and act as a control group. Animals were injected with streptozocin (STZ; 30 $\mathrm{mg} / \mathrm{kg}, \mathrm{IP}$ ) to induce diabetes, and animals were treated with saline (Group II) or EPO (300 iu//kg, IP Group III) or insulin (3 iu//kg, s.c., group IV) respectively, for three successive weeks. STZ-induced diabetes was indicated by hyperglycemia. Further, Results: Three weeks after EPO treatment, there was an enhanced blood glucose level associated with enhanced glucose tolerance and insulin sensitivity tests $(\mathrm{P}<0.05)$. Moreover, $\mathrm{C}$ peptide showed a significant increase $\quad(\mathrm{P}<0.05)$.
\end{abstract} Conclusion: EPO-treatment in rats was associated with improved diabetes.

Keywords: Erythropoietin, Hypoglycemia, Diabetes, Rat

\section{Introduction}

$\mathrm{DM}$ is a very common metabolic disorder spreading worldwide at a very high rate with the expectation that the number of affected individuals during the next twenty years is going to be twice [1]. The main pathophysiology of this disease is insulin insufficiency due to either severe deficiency caused by damaged pancreatic $\beta$-cell or tissue resistance to insulin action. Thus, an insufficient supply of insulin hormone leads to hyperglycemia and progression to overt diabetes [2].

DM is classified by the World Health Organization (WHO) and American diabetes association (ADA) into four types: type1 DM, type 2 DM, gestational diabetes and other specific types [3]. The problem with DM is its complications either acute as hypoglycemia and hyperglycemic crisis or chronic microand macrovascular complications that affect most of the body systems leading to recurrent hospitalization and decrease the quality of life [4].

Erythropoietin (EPO) is a cytokine hormone. Its secretion from the kidney by $85 \%$ and the liver by $15 \%$ is stimulated mainly by hypoxia [5]. It acts on its receptors present on the surface of erythroid progenitor cells present in the bone marrow to help them to proliferate 
and differentiate into mature red blood cells [6].

Erythropoietin is not only secreted from kidney and liver and erythropoietin receptors are not expressed in the erythroid progenitor cells only but both are found to exist in the brain, heart, pancreas, endothelial cells, adipose tissue, liver, female organs, and skeletal muscle myoblasts [7]. This is proved by the discovery that erythropoietin has other non-hematopoietic function as metabolic functions, anti-inflammatory, anti-oxidant, and angiogenesis. These non-erythropoietic functions of erythropoietin have erased the question about the benefit of erythropoietin as a treatment of DM in comparison with insulin traditional therapy.

The work aims to determine if erythropoietin can control the blood glucose level of diabetic rats.

\section{Material and Methods}

Place of the study: Physiology Department, Faculty of Medicine, Sohag University

Type of the study: Experimental study. Study period: From September 2017 to June 2018.

\section{Animals}

Eighty adult albino rats about 3-4 months old with average body weight $(225 \pm 25 \mathrm{gm})$, were obtained from the Faculty of Science, Sohag University and were housed in Animal experimental units in Sohag faculty of medicine, animals gained free access to food and tap water. Every 4 rats were housed in metal cages $(20 \times 32 \times 20 \mathrm{~cm})$ at normal light/dark cycle and room temperature. The study was approved by Research Ethics Committee considering the care and use of laboratory animals.

\section{Reagents}

Streptozocin (Sigma-Aldrich, St. Louis, MO, USA) was purchased to induce diabetes. Epoetin (alpha recombinant human erythropoietin, medico, Egypt) was purchased for usage as a line of treatment. Humulin R (Short-acting insulin, Lilly, Israel) was purchased to be used as a line of treatment for different groups. Rat C Peptide kit (SG20090, Sinogenecloncompany, China) for the measurement of serum $\mathrm{C}$ peptide.

\section{Experimental protocol}

The eighty rats were divided into 4 equal groups $(n=20)$. Animals were left for one week for accommodation.

\section{Group I (GI), control group (CG):}

Twenty Healthy rats were injected by saline intraperitoneally for 3 weeks

Group II (GII), diabetic group (DG):

Twenty Diabetic rats were injected by streptozocin then saline intraperitoneally for 3 weeks

Group III (GIII), diabetic with erythropoietin treated group (DE):

Twenty rats of diabetes were induced in them as in group 2 then were injected by erythropoietin at a dose of $300 \mathrm{IU} / \mathrm{kg}$ intraperitoneally three times a week for 3 weeks [8].

\section{Group IV (GIV), diabetic taking insulin group (DI):}

Twenty rats of diabetes were induced in them as in group 2 then were injected by insulin at a dose of $3 \mathrm{IU} / \mathrm{kg}$ subcutaneously daily for 3 weeks.

\section{Induction of Diabetes Mellitus}

Rats fasted overnight in specific cages. The next day, streptozocin was dissolved in $\mathrm{Na}$ citrate buffer $(\mathrm{pH}=4,5)$. Streptozocin then used in a single dose of $35 \mathrm{mg} / \mathrm{kg}$ and given by intraperitoneal to induce diabetes [9]. An equivalent volume of saline was administered to the 
non-diabetic controls. After 72 hours of fasting blood glucose (FBG) levels were measured using blood samples taken from the rat tail vein. Rats said to be diabetic when FBG equal to or greater than $150 \mathrm{mg} / \mathrm{dl}$ [10].

Treatment then started for all groups. At day 11 blood glucose level was measured by skin puncture of the tail using glucometer in all groups.

At the end of the three weeks of experiment 2 , the following was done At the end of the 3 weeks

1. Blood glucose: Was measured by skin puncture of the tail using glucometer in all groups [11]

\section{Intraperitoneal glucose tolerance} test (IPGTT): The rats have fasted for 6 hours. A saline EPO/insulin solution at the indicated dose or the same volume of saline was injected intraperitoneally (IP). Thirty minutes later, blood glucose measured (0 times). Next, $2 \mathrm{~g} / \mathrm{kg}$ of glucose (saline in the control group). Blood glucose then was measured 30, 60, 90, and 120 minutes after the IP glucose loading by skin puncture of rat tail [12] 3. Assay of insulin sensitivity Rats fasted for 12 hours then insulin at a dose of $4 \mathrm{U} / \mathrm{kg}$ is injected subcutaneously. Then the blood glucose was measured 0, 30, 60, 90 and 120 min following injection by skin puncture of rat tail [13].

\section{Sampling}

At the end of the 3 weeks of the experimental period, all animals were anesthetized and then before scarifying them intracardiac blood sample is taken 1- Half of the fresh sample used to measure hemoglobin A1C (HBA1C) and hematocrit value

2- The other half were kept in a $37^{\circ} \mathrm{C}$ water bath for 30 minutes to enhance coagulation then centrifuged at 3000 rpm for 10 minutes, serum samples were separated to measure the level of $\mathrm{C}$ peptide and preserved at $-20^{\circ} \mathrm{C}$ till the time of biochemical assay.

\section{Biochemical assay:}

The levels of serum $\mathrm{C}$ peptide was measured using rat $\mathrm{C}$ peptide (CP) Elisa Kit (Sandwich Method) according to the manufacturer's instructions (SG-20090, Sinogeneclon company, China) as follows: The wells of plastic plates were coated with

Purified CP antibody then serum samples containing $\mathrm{C}$ peptide are added. The wells then covered with an adhesive strip and incubated for $30 \mathrm{~min}$ at 37degree centigrade. Washing buffer then added and drained 5 times. Then 50

L of HRP-Conjugate reagent is added to each well. 50 L of each of Chromogen solution $\mathrm{A}$ and Chromogen solution B is added after incubation and adding washing buffer for the second time. The reaction then was stopped by adding 50 L of stop solution to each well the results were then read within 15 min.

\section{Statistical analysis}

Data were analyzed using the SPSS version 19 software. One way ANOVA was used. Tukey post hoc was selected for group comparison. In the case of blood glucose level, intraperitoneal glucose tolerance test and insulin sensitivity test Two Way Anova repeated measures were used and Mauchly' s test was used as a post hoc test. Data were considered significant if the $\mathrm{P}$-value was $<0.05$.

\section{Results}

\section{1- Blood glucose level}

Results of this study showed that the erythropoietin treated group had a 
SOHAG MEDICAL JOURNAL

Vol. 24 No. 1 Jan 2020

statistically significant decrease in blood glucose level in diabetic rats after 3 weeks of erythropoietin injection in comparison to the diabetic group treated with saline only which had high blood glucose level and remained diabetic till the end of the three weeks. Erythropoietin also caused a statistically significant decrease of HBA1C, improved glucose tolerance, a statistically significant increase in serum $\mathrm{C}$ peptide level and improvement in insulin sensitivity of diabetic rats in comparison to the diabetic group treated with saline only. Insulin given diabetic group had a more statistically significant

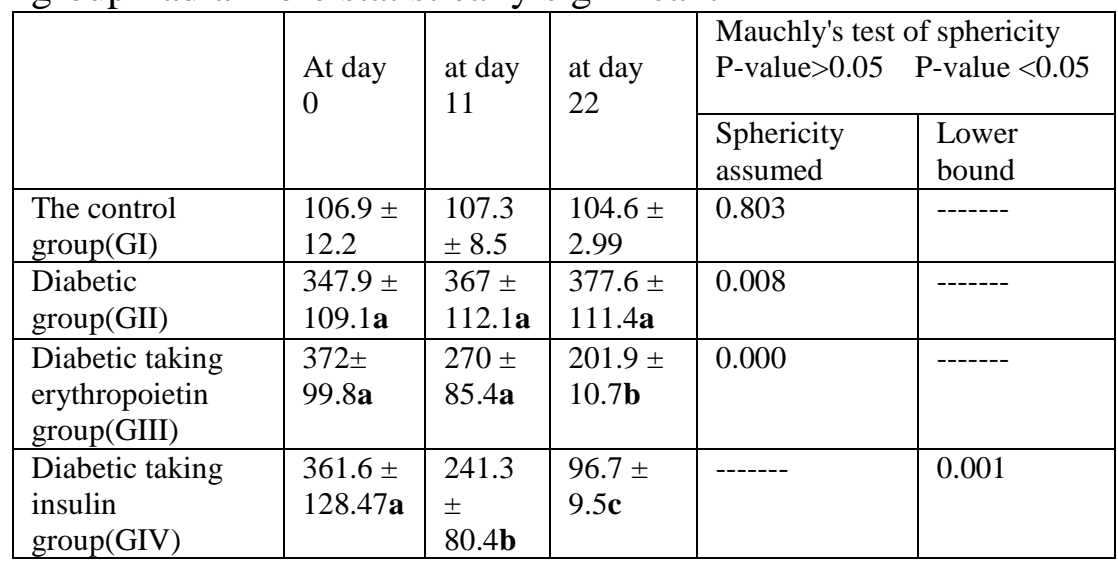

Table (1): Effect of erythropoietin (EPO) on random blood glucose level during the whole experiment

Data are expressed as mean \pm SD, values with different letters mean significant

P-Value was calculated by repeated measures two-way ANOVA test. Statistically significant p-value $<0.05$.

\begin{tabular}{|c|l|l|l|l|l|}
\hline & $\begin{array}{l}\text { Control } \\
\text { group(GI) }\end{array}$ & $\begin{array}{l}\text { Diabetic } \\
\text { group(GII } \\
\text { grout }\end{array}$ & $\begin{array}{l}\text { Diabetic taking } \\
\text { erythropoietin } \\
\text { group(GIII) }\end{array}$ & $\begin{array}{l}\text { Diabetic } \\
\text { taking } \\
\text { insulin } \\
\text { group(GIV) }\end{array}$ & $\begin{array}{l}\text { P- } \\
\text { value }\end{array}$ \\
\hline $\begin{array}{l}\text { Hematocrit } \\
\text { value }\end{array}$ & $\begin{array}{l}40.3 \pm \\
3.4 \mathbf{b}\end{array}$ & $\begin{array}{l}39.7 \pm \\
2.1 \mathbf{b}\end{array}$ & $\begin{array}{l}44.7 \pm \\
2.6 \mathbf{a}\end{array}$ & $\begin{array}{l}39.4 \pm \\
2.6 \mathbf{b}\end{array}$ & 0.004 \\
\hline HBA1C & $5.7 \pm$ & $12 \pm$ & $6.1 \pm$ & $6 \pm$ & 0.000 \\
& $1.04 \mathbf{b}$ & $1.8 \mathbf{a}$ & $0.8 \mathbf{b}$ & $0.9 \mathbf{b}$ & \\
\hline C peptide & $0.063 \pm$ & $0.036 \pm$ & $0.062 \pm$ & $0.039 \pm$ & 0.000 \\
& $0.004 \mathbf{a}$ & $0.01 \mathbf{b}$ & $003 \mathbf{a}$ & $0.01 \mathbf{b}$ & \\
\hline
\end{tabular}

Table (2): Effect of erythropoietin (EPO) on hematocrit value, HBA1C and C peptide in diabetic rats

Data are expressed as mean \pm standard deviation, Values with different letters are significant P-Value was calculated by One Way-Anova test, Statistically significant p-value $<0.05$. 
SOHAG MEDICAL JOURNAL

Vol. 24 No. 1 Jan 2020
Possible effects of erythropoietin on diabetic rats Walaa Mohamed Shaaban

Table (3): Effect of erythropoietin (EPO) on glucose tolerance in diabetic rats

\begin{tabular}{|c|c|c|c|c|c|c|c|}
\hline \multirow{2}{*}{$\begin{array}{c}\text { Groups } \\
120 \text { min }\end{array}$} & \multirow[t]{2}{*}{ at $0 \mathrm{~min}$} & \multirow{2}{*}{\multicolumn{2}{|c|}{$30 \mathrm{~min}$}} & \multirow[t]{2}{*}{$\min$} & \multirow[t]{2}{*}{$90 \mathrm{~min}$} & \multirow{2}{*}{\multicolumn{2}{|c|}{$\begin{array}{l}\text { Mauchley test of sphericity } \\
\text { P-value }>0.05 \quad \text { P-value }<0.05\end{array}$}} \\
\hline & & & & & & & \\
\hline & & & & & & \multirow{2}{*}{$\begin{array}{l}\text { Sphericity } \\
\text { assumed }\end{array}$} & \multirow{2}{*}{$\begin{array}{c}\text { P-value }<0.05 \\
\text { Lower bound } \\
0.001\end{array}$} \\
\hline $\begin{array}{l}\text { Control } \\
\text { group }(\mathrm{GI})\end{array}$ & $\begin{array}{l}106.14 \\
\pm 7.7 \mathbf{b}\end{array}$ & $\begin{array}{l}296 \pm \\
87.6 \mathbf{a}\end{array}$ & $\begin{array}{l}256.3 \pm \\
34.8 \mathbf{a}\end{array}$ & $\begin{array}{l}177.9 \pm \\
39 \mathbf{a}\end{array}$ & $\begin{array}{l}107.1 \pm \\
8.6 \mathbf{b}\end{array}$ & & \\
\hline $\begin{array}{l}\text { Diabetic } \\
\text { group(GII) }\end{array}$ & $\begin{array}{l}359 \pm \\
130.7 \mathbf{b}\end{array}$ & $\begin{array}{l}528.6 \pm \\
126.7 \mathbf{a}\end{array}$ & $\begin{array}{l}520.6 \pm \\
128.6 \mathbf{a}\end{array}$ & $\begin{array}{l}501.3 \pm \\
108.2 \mathbf{a}\end{array}$ & $\begin{array}{l}526.6 \pm \\
126.1 \mathrm{a}\end{array}$ & 0.007 & ------ \\
\hline $\begin{array}{l}\text { Diabetic } \\
\text { taking } \\
\text { erythropoietin } \\
\text { group }\end{array}$ & $\begin{array}{l}198 \pm \\
11.1 \mathrm{c}\end{array}$ & $\begin{array}{l}459.1 \pm \\
54.1 \mathrm{a}\end{array}$ & $\begin{array}{l}393.7 \pm \\
54.9 \mathbf{b}\end{array}$ & $\begin{array}{l}312.9 \pm \\
38.6 \mathbf{b}\end{array}$ & $\begin{array}{l}257.9 \pm \\
21.9 \mathbf{b}\end{array}$ & 0.000 & ------ \\
\hline $\begin{array}{l}\text { Diabetic } \\
\text { taking insulin } \\
\text { group }\end{array}$ & $\begin{array}{l}100 \pm \\
7.23 \mathbf{c}\end{array}$ & $\begin{array}{l}373.71 \pm \\
43.2 \mathbf{a}\end{array}$ & $\begin{array}{l}298 \pm \\
61.87 b\end{array}$ & $\begin{array}{l}196.14 \pm \\
47.78 \mathbf{b}\end{array}$ & $\begin{array}{l}98.86 \pm \\
10.21 \mathrm{c}\end{array}$ & ------ & 0.000 \\
\hline
\end{tabular}

Data are expressed as mean $\pm \mathrm{SD}$, values with different letters mean significant

P-Value was calculated by Repeated measures Two Way-Anova test. Statistically significant p-value $<0.0$

Table (4): Effect of Erythropoietin (EPO) on insulin sensitivity in diabetic rats.

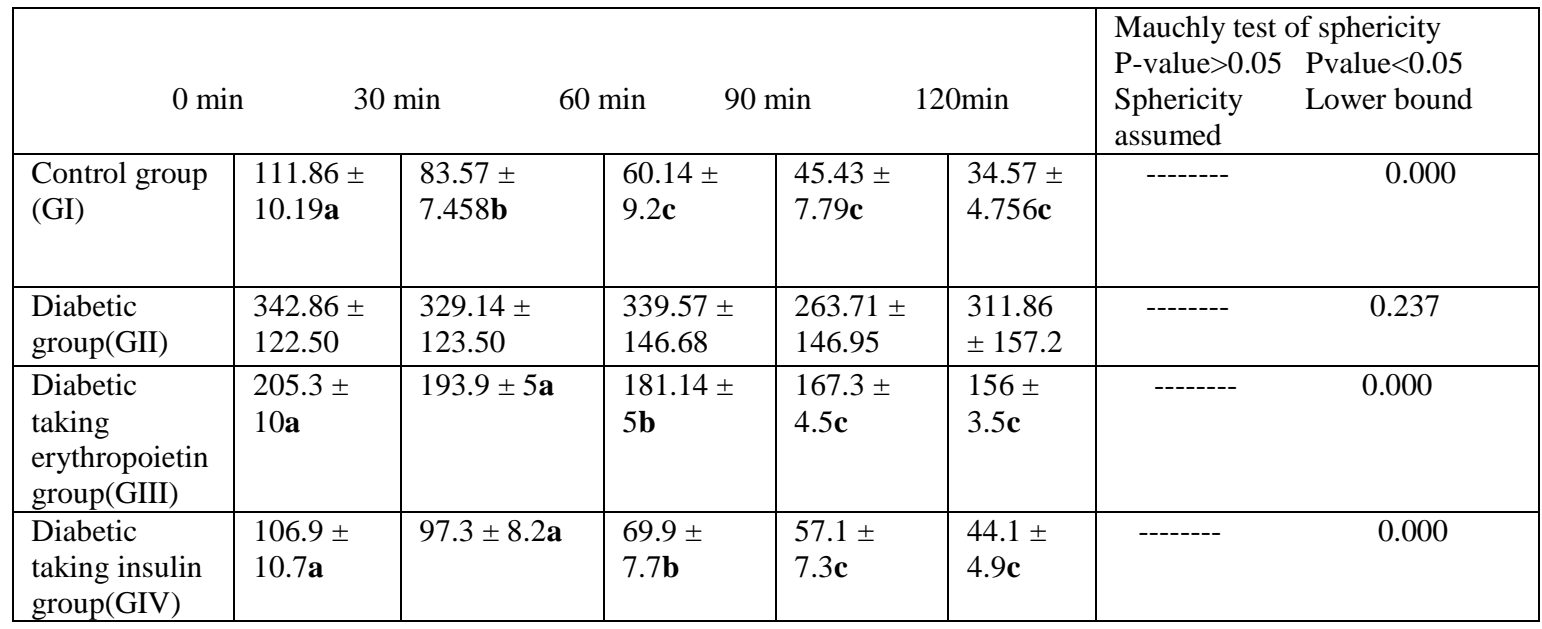

Data are expressed as mean \pm SD, values with different letters mean significant P-Value was calculated by Repeated measures Two Way Anova test. Statistically significant p-value $<0.05$

\section{Discussion}

Erythropoietin (EPO) is a growth factor. Its main function is to stimulate the formation of new red blood cells in bone marrow [14]. EPO is highly used to treat anemia in diabetic patients with chronic kidney disease [15] . The main factor that causes different complications of diabetes is hyperglycemia. Hyper- glycemia causes damage to mesangial cells is implicated in causing the development of diabetic nephropathy and the other different complications of diabetes [16].

Is there a hypoglycemic effect for EPO, it is a matter of debate. 
SOHAG MEDICAL JOURNAL

Vol. 24 No. 1 Jan 2020

First, this study found that there was a significant decrease in blood glucose level in the erythropoietin treated diabetic group over the three weeks of treatment by erythropoietin in comparison to the diabetic group treated with the only saline over the three weeks. This result agreed with [13] who said that erythropoietin helped to decrease blood glucose levels in streptozocin-induced diabetic rats. However, there was a more significant decrease in blood glucose level in the insulin-treated diabetic group for three weeks in comparison to the erythropoietin treated diabetic group. This was in parallel with [17] who said that insulin therapy associated with continuous glucose monitoring systems is the best method to control blood glucose levels of diabetic patients.

In this study also, there was a decrease in HBA1C in erythropoietin treated diabetic group when compared to the diabetic group treated with only saline which agreed with [18] who found that there was a good control on blood glucose level and decrease in HBA1C level by using a nonhematopoietic peptide derivative of erythropoietin as a treatment for diabetes. Also, the results of this study found a marked decrease of $\mathrm{H} 1 \mathrm{Ac}$ level in the insulin-treated diabetic group in comparison to the diabetic group which also agreed with [19].

The above results showed erythropoietin's ability to control blood glucose levels. This ability can be explained by the improvement in glucose tolerance, insulin sensitivity and increase serum $\mathrm{C}$ peptide after 3 weeks of treatment by erythropoietin.

Regarding glucose tolerance, our results in this study showed a significant improvement in glucose tolerance tests associated with a decrease in blood glucose level in the erythropoietin treated group in comparison to the diabetic group. This result was similar to [13] who said that erythropoietin had an important role in improving glucose tolerance in diabetes mellitus. But disagreed with [20] who said that erythropoietin did not improve glucose tolerance in human patients having diabetes and complicated with chronic kidney disease. On the other hand, a marked decrease in blood glucose level with high improvement in glucose tolerance test in the insulin-treated diabetic group in comparison to erythropoietin treated diabetic group which agreed with [21].

Also, the results of the insulin sensitivity test revealed that (GIII) had a significant improvement in insulin sensitivity associated with a decrease in blood glucose level in comparison to diabetic group (GII). This result was similar to [13] but was different from [20] who found that erythropoietin did not have any effect on insulin sensitivity in streptozocin induced diabetic male mice. Also, the insulin-treated diabetic group had a more significant improvement of insulin sensitivity in comparison to diabetic taking erythropoietin group erythropoietin treated diabetic group. This result agreed with [22] who said that insulin therapy used for type 2 diabetic patients caused decreased insulin resistance so much.

The ability of erythropoietin to improve insulin sensitivity and glucose tolerance in diabetic rats is because its action on its main receptors on skeletal muscle and liver causing stimulation of certain intracellular signaling pathway which helps GLUT4 translocation to the cell surface and increase glucose uptake by liver and skeletal muscle [23] and this 
helped erythropoietin to decrease blood glucose level of diabetic rats.

$\mathrm{C}$-peptide is considered to be a very good indicator of insulin secretion inside the body of diabetic patients as both (Insulin and $\mathrm{C}$ peptide) are produced in equal amounts by the human body [24].

In this study, there was a significant increase in serum $\mathrm{C}$ peptide level in erythropoietin treated diabetic group when compared to diabetic group and insulin-treated diabetic group which indicates improvement in pancreatic function as said by [8] who found that erythropoietin promotes cellular growth and survival making it have a highly protective effect on the pancreatic beta cells. Insulin treated diabetic group had a statistically significant low level of serum $\mathrm{C}$ peptide in comparison to the erythropoietin treated diabetic group. This agreed with [25] who said that there was a progressive decline in the $\mathrm{C}$ peptide level as the diabetes progress even with insulin treatment.

The results in this study revealed a significant high level of $\mathrm{HV}$ in diabetic taking erythropoietin group in comparison to the control group (GI) and diabetic group (GII) which may aggravate thromboembolism in erythropoietin treated patients. On the other hand, a marked decrease of $\mathrm{HV}$ value was observed in diabetic taking insulin groups when compared to diabetic taking erythropoietin group which makes insulin an ideal therapy for diabetes besides its low cost in comparison erythropoietin.

\section{Conclusion:}

Finally to sum our results showed that erythropoietin could control hyperglycemia and improve glucose tolerance and insulin sensitivity in diabetic rats, but this effect is not as high as that of insulin.

\section{$\underline{\text { References }}$}

1. Zaccardi, F., et al., Pathophysiology of type 1 and type 2 diabetes mellitus: a 90year perspective. Postgraduate medical journal, 2016. 92(1084): p. 63-69.

2. Kharroubi, A.T. and H.M. Darwish, Diabetes mellitus: The epidemic of the century. World journal of diabetes, 2015. 6(6): p. 850-867.

3. Baynes, H., Classification, pathophysiology, diagnosis and management of diabetes mellitus. $\mathrm{J}$ diabetes metab, 2015. 6(5): p. 1-9.

4. Chaudhury, A., et al., Clinical Review of Antidiabetic Drugs: Implications for Type 2 Diabetes Mellitus Management. Frontiers in Endocrinology, 2017. 8(6).

5. Obeagu, E.I., A. Ezimah, and G.U. Obeagu, Erythropoietin in the Anaemias of Pregnancy: A Review. Int J Curr Res Chem Pharm Sci, 2016. 3(3): p. 10-8.

6. Gutti, U., et al., Erythropoietin and thrombopoietin mimetics: Natural alternatives to erythrocyte and platelet disorders. Critical reviews in oncology/hematology, 2016. 108: p. 175186.

7. Wang, L., L. Di, and C.T. Noguchi, Erythropoietin, a novel versatile player regulating energy metabolism beyond the erythroid system. International journal of biological sciences, 2014. 10(8): p. 921.

8. Chen, L.N., et al., Erythropoietin improves glucose metabolism and pancreatic $\beta$-cell damage in experimental diabetic rats. Molecular medicine reports, 2015. 12(4): p. 5391-5398.

9. Satyam, S.M., K. Bairy, and R. Pirasanthan, Influence of Grape seed extract and Zincovit tablets (Nutritional food supplement) on glucose level in normal and streptozocin induced diabetic rats. Int J Pharm Sci, 2013. 5(3): p. 413416.

10.Natarajan, V. and A.S.A.G. Dhas, Effect of active fraction isolated from the leaf extract of Dregea volubilis [Linn.] Benth. on plasma glucose concentration and lipid profile in streptozotocin-induced 
SOHAG MEDICAL JOURNAL

Vol. 24 No. 1 Jan 2020

diabetic rats. SpringerPlus, 2013. 2(1): p. 394.

11.Caillaud, C., et al., Chronic erythropoietin treatment improves dietinduced glucose intolerance in rats. 2015.

12.Meng, R., et al., Erythropoietin inhibits gluconeogenesis and inflammation in the liver and improves glucose intolerance in high-fat diet-fed mice. PloS one, 2013. 8(1): p. e53557.

13.Niu, H.-S., et al., Erythropoietin ameliorates hyperglycemia in type 1-like diabetic rats. Drug design, development and therapy, 2016. 10: p. 1877.

14.Chan, S.J., et al., Endogenous regeneration: Engineering growth factors for stroke. Neurochemistry international, 2017. 107: p. 57-65.

15.Cheng, H.W.B., et al., Use of erythropoietin-stimulating agents (ESA) in patients with end-stage renal failure decided to forego dialysis: Palliative perspective. American Journal of Hospice and Palliative Medicine ${ }^{\circledR}, 2017$. 34(4): p. 380-384.

16.Shi, G.-J., et al., Involvement of growth factors in diabetes mellitus and its complications: a general review. Biomedicine \& Pharmacotherapy, 2018. 101: p. 510-527.

17.Chamberlain, J.J., et al., Diagnosis and management of diabetes: synopsis of the 2016 American Diabetes Association Standards of Medical Care in Diabetes. Annals of internal medicine, 2016. 164(8): p. 542-552.

18.Brines, M., et al., ARA 290, a nonerythropoietic peptide engineered from erythropoietin, improves metabolic control and neuropathic symptoms in patients with type 2 diabetes. Molecular
Possible effects of erythropoietin on diabetic rats Walaa Mohamed Shaaban

medicine (Cambridge, Mass.), 2015. 20(1): p. 658-666.

19.Zinman, B., Newer insulin analogs: advances in basal insulin replacement. Diabetes, Obesity and Metabolism, 2013. 15(s1): p. 6-10.

20.Choi, D., et al., Erythropoietin protects against diabetes through direct effects on pancreatic $\beta$ cells. Journal of Experimental Medicine, 2010. 207(13): p. 2831-2842.

21.Gu, H., et al., Insulin therapy improves islet functions by restoring pancreatic vasculature in high-fat diet-fed streptozotocin-diabetic rats (

). Journal of diabetes, 2014. 6(3): p. 228-236.

22.Kramer, C.K., B. Zinman, and R. Retnakaran, Short-term intensive insulin therapy in type 2 diabetes mellitus: a systematic review and meta-analysis. The lancet Diabetes \& endocrinology, 2013. 1(1): p. 28-34.

23.Pan, Y., et al., Erythropoietin Reduces Insulin Resistance via Regulation of Its Receptor-Mediated Signaling Pathways in $d b / d b$ Mice Skeletal Muscle. International journal of biological sciences, 2017. 13(10): p. 1329-1340.

24.Jones, A. and A. Hattersley, The clinical utility of $C$-peptide measurement in the care of patients with diabetes. Diabetic Medicine, 2013. 30(7): p. 803-817.

25.Hao, W., et al., Fall in C-peptide during first 4 years from diagnosis of type 1 diabetes: variable relation to age, HbAlc, and insulin dose. Diabetes care, 2016. 39(10): p. 1664-1670. 